Article

\title{
An Intelligent Controlling Method for Battery Lifetime Increment Using State of Charge Estimation in PV-Battery Hybrid System
}

\author{
Md Ohirul Qays ${ }^{1} @$, Yonis Buswig ${ }^{1}$, Hazrul Basri ${ }^{1}$, Md Liton Hossain ${ }^{2}{ }^{\circledR}$, Ahmed Abu-Siada ${ }^{2}$, \\ Md Momtazur Rahman ${ }^{3}$ and S. M. Muyeen ${ }^{2, *(\mathbb{D})}$ \\ 1 Department of Electrical and Electronic Engineering, Faculty of Engineering, Universiti Malaysia \\ Sarawak (UNIMAS), Kota Samarahan 94300, Sarawak, Malaysia; 18020101@siswa.unimas.my (M.O.Q.); \\ byonis@unimas.my (Y.B.); mbhazrul@unimas.my (H.B.) \\ 2 Department of Electrical and Computer Engineering, Curtin University, Kent Street, Bentley, \\ Perth, WA 6102, Australia; mdliton.hossain@postgrad.curtin.edu.au (M.L.H.); \\ A.AbuSiada@curtin.edu.au (A.A.-S.) \\ 3 Electron Science Research Institute, Edith Cowan University, 270 Joondalup Drive, \\ Joondalup, WA 6027, Australia; mohammad.rahman@ecu.edu.au \\ * Correspondence: Sm.Muyeen@curtin.edu.au
}

Received: 16 October 2020; Accepted: 5 December 2020; Published: 9 December 2020

\begin{abstract}
In a photovoltaic (PV)-battery integrated system, the battery undergoes frequent charging and discharging cycles that reduces its operational life and affects its performance considerably. As such, an intelligent power control approach for a PV-battery standalone system is proposed in this paper to improve the reliability of the battery along its operational life. The proposed control strategy works in two regulatory modes: maximum power point tracking (MPPT) mode and battery management system (BMS) mode. The novel controller tracks and harvests the maximum available power from the solar cells under different atmospheric conditions via MPPT scheme. On the other hand, the state of charge (SOC) estimation technique is developed using backpropagation neural network (BPNN) algorithm under BMS mode to manage the operation of the battery storage during charging, discharging, and islanding approaches to prolong the battery lifetime. A case study is demonstrated to confirm the effectiveness of the proposed scheme which shows only $0.082 \%$ error for real-world applications. The study discloses that the projected BMS control strategy satisfies the battery-lifetime objective for off-grid PV-battery hybrid systems by avoiding the over-charging and deep-discharging disturbances significantly.
\end{abstract}

Keywords: backpropagation neural network (BPNN); battery management system (BMS); dSPACE 1104; energy storage; PV-battery integration; state of charge (SOC)

\section{Introduction}

Photovoltaics (PVs) have been widely used as a reliable and cost effective renewable energy source in order to reduce the dependency on fossil fuels conventional generation [1]. The performance of PV systems can be investigated through detailed modeling and simulation analysis [2]. In this regard, artificial neural network (ANN) model for PV system has been recently used instead of the classical one diode and five parameters (1D + 5P) model. While the ANN model revealed a better performance, the execution time is long with large data required for training and testing the ANN model. The PV cells are classified into two main categories, namely, double diode and single diode modules [3,4]. While high accuracy PV panel is characterized by double diode module, the structural complexity depicts low analytical speed. Thus, the equitable trades between accuracy and easiness give advantage for single 
diode module to be adopted in various power electronics applications [5]. The implementation of PV systems presented in [6-8] suggested to conduct further research on PV-battery hybrid system.

Irregularity of solar irradiance and atmospheric temperature degrades the efficiency of the solar panel. This calls for the adoption of a reliable maximum power point tracking (MPPT) scheme to harvest the maximum available power from the solar irradiance. The purpose of MPPT is to match the I-V operating point of the PV modules and yield the maximum available power from the electronic converter $[9,10]$. Various online and offline MPPT techniques are presented in [11] in which, a combination of adaptive neuro-fuzzy inference system (ANFIS) and hill climbing (HC) MPPT technique is developed. Reported results outperform the tracking accuracy of the conventional MPPT technique. In [12], an adaptive perturb and observation (P\&O) MPPT algorithm is developed to improve the yield of the PV system during partial shading events. The designed system is applicable for mono and polycrystalline-based PV panels. In [13], an improved P\&O MPPT technique is developed and tested under a step and ramp changes of solar irradiation. The proposed method is reported to be of a faster tracking speed than the conventional method. Moreover, a modified P\&O based MPPT technique implemented in MATLAB/SIMULINK software is presented in [14]. This algorithm was able to identify the maximum power point accurately compared to the conventional P\&O scheme. Nevertheless, experimental validation of the proposed technique was recommended in future research accompanied by the impact of temperature parameter. Consequently, by following [15], P\&O based MPPT system is used in this research to improve the working prototype in real-life application.

Throughout the night-time plus cloudy days, only PV panel cannot afford to deliver sufficient power-supply that evocates in terms of energy storage system or another source of power-generation. PV-diesel system is widely used in remote area to provide uninterrupted power. However, the use of diesel generator may have severe consequences on the environment due to its dependency on fossil fuels [16]. Therefore, battery energy storage system (BESS) is another preferred option to maintain the power system efficiency in full-fledged [17-19]. The charging/discharging irregularity of PV-battery hybrid system decreases the battery operational life and affects the entire system efficiency. In general, lead acid battery comprises a flat terminal voltage in the range of $40 \%$ to $80 \%$ of the state of charge (SOC) [20]. As shown in Figure 1, the voltage variation in this range is less than 0.44 V. A minor difference of the open circuit voltage $\left(\mathrm{V}_{\mathrm{OC}}\right)$ in this scope causes a significant variation in the system performance as $\mathrm{V}_{\mathrm{OC}}$ is directly related to the SOC. Such slight voltage difference can hardly be used to persuade a proper charging and discharging process.

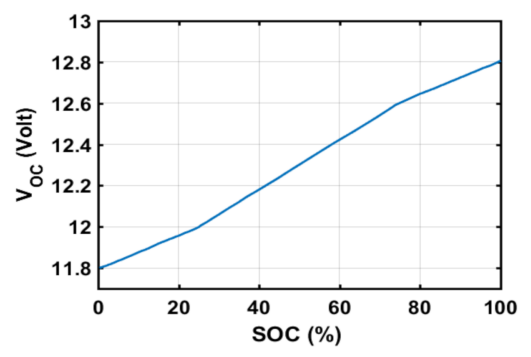

Figure 1. Open circuit voltage $\left(\mathrm{V}_{\mathrm{OC}}\right)$ vs. state of charge (SOC) for the employed $12 \mathrm{~V}$ Lead-Acid battery.

Principally, SOC estimation accuracy ensures the integral efficiency of the battery storage system [21]. The optimization of lithium-ion battery (LIB) model parameters are distinctly degraded by the unexpected noises in the real-life applications [22,23]. To discern this labyrinth, instrumental variable (IV) estimation was combined with the bilinear principle in [24] headed for compensating the noise-induced biases of battery parameterization. Luenberger observer was further implemented in the proposed model that resulted in $2.60 \%$ and $1.25 \%$ SOC estimation error under hybrid pulse experiment (HPE) and federal urban dynamic schedule (FUDS) condition correspondingly.

Reference [25] presented backpropagation neural network (BPNN) based SOC estimation technique for Lithium-ion battery at three different temperatures $\left(0,25\right.$ and $\left.45^{\circ} \mathrm{C}\right)$. The research resulted the reduction of root mean square error (RMSE) for BPNN model at $25^{\circ} \mathrm{C}$ compared to radial basis 
neural network, extreme learning machine, and generalized regression neural network models. The LabVIEW-DAQ 6008 was implemented in [26] to devise the optimum employment of lead-acid battery through BPNN based SOC assessment algorithm. This research resulted $0.893 \%$ average error by recommending the battery life extension for future research. Reference [27] implemented Wöhler-curve-based ageing model to improve the battery lifespan that recommended a proper controlling scheme in case of railway application. In [28], a predictive controller system is proposed to manage the SOC of the battery bank and support the critical load demand during grid-blackout condition. The projected model elongated the battery lifetime excluding off-grid atmosphere. According to the above discussion, BPNN based SOC estimation approach is a better solution compared to the existing research in the direction of lengthening the battery lifespan for PV-battery hybrid system. Therefore, the main contribution of this paper is the development of a proper control strategy for a standalone PV-battery integrated system to manage the generation and load-demand operation. Further, an effective SOC estimation technique is proposed to extend the operational life of a lead acid battery. The proposed model is validated through extensive simulation and experimental analyses using MATLAB-dSPACE 1104 interfacing system.

The remaining of this paper is organized as follows: The modeling approach for state of charge (SOC) estimation is explained in Section 2. Section 3 represents the numerical simulation and experimental analysis in depth. The significance of the proposed methodology are elucidated based on simulated and experimental results in Section 4. In Section 5, the key conclusion of the paper is drawn.

\section{State of Charge (SOC) Estimation}

State of charge (SOC) is essential for Lead Acid (LA) battery to declare its well-being operation and to eliminate over-charging/deep-discharging issues. However, the complexity of the electrochemical responses marks the SOC estimation as a challenging subject [29-31]. In case of nonlinear systems, BPNN is the most employed technique because of its self-learning and feedback distinction [25,32]. Thus, BPNN based SOC assessment method is adopted in this paper as shown in Figure 2. As mentioned in Figure 3, SOC is estimated for every single battery independently by collecting its voltage and current parameters where $\mathrm{V}_{\mathrm{T}}$ is the total voltage of the battery bank. The root mean square error (RMSE) of the SOC estimation is minimized by adjusting the weights. In BPNN, total input of the hidden layer can be calculated from,

$$
n e t i_{n}=\sum_{i=1}^{3} x_{i} w_{i n}+b_{n}
$$

where neti $_{n}$ represents the total input to the hidden layer neuron $n, x_{i}$ symbolizes the value of input neuron, $w_{\text {in }}$ deliberates the weight between the input layer and hidden layer neurons $i$ and $n$; respectively, bias of the hidden layer neuron $n$ is mentioned as $b_{n}$.

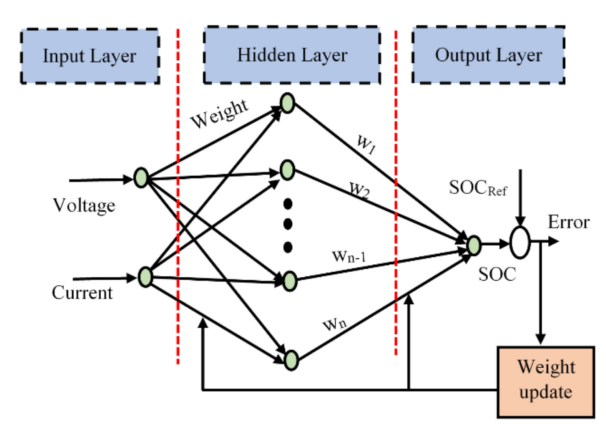

Figure 2. Structural design of the proposed backpropagation neural network (BPNN) algorithm. 


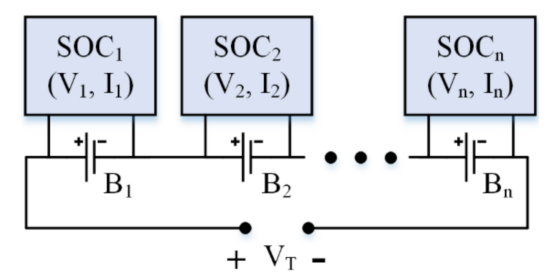

Figure 3. State of charge (SOC) estimation maneuver from batteries.

A tangent function is the utilized activation function for the hidden layer neuron $n$. The valuation of the output layer neuron can be found from (3).

$$
\begin{gathered}
h_{n}=f\left(\text { neti }_{n}\right)=\frac{1-\exp \left(-2 \text { net } i_{n}\right)}{1+\exp \left(-2 \text { net }_{n}\right)} \\
\text { neto }=\sum_{i=1}^{n} h_{i} g_{i}+p
\end{gathered}
$$

where neto represents the overall product of the output layer neuron $o$, the value of hidden layer neuron to output layer neuron for $i$ is $h_{i}$, weight between hidden layer neuron $i$ and output layer neuron $o$ is $g_{i}$, bias of the output layer neuron $o$ is $p$.

Sigmoid function is used as the applied activation function of the output layer neuron where output $y_{n}$ can be calculated from (4)

$$
\begin{gathered}
y_{n}=f(\text { neto })=\frac{1}{1+\exp (-n e t o)} \\
e_{i}=f_{\text {Ref }}-f_{\text {Est }} \\
\frac{\partial E r r o r}{\partial w_{i j}^{n}}=\frac{\partial E r r o r}{\partial f_{\text {Est }}} \frac{\partial f_{E s t}}{\partial w_{i j}^{n}} \\
R M S E=\sqrt{\left(\sum_{i=1}^{n} e_{i}^{2}\right) / n}
\end{gathered}
$$

where $e_{i}$ represents the output error, $f_{R e f}$ and $f_{E s t}$ are the reference output function and estimated output function; respectively. Using gradient descent algorithm (GDA) as given by (5) to (7), weights are restructured repeatedly to attain the expected output and reduce the error. From (7) the RMSE is considered from which the improved weights are achieved while the error is diminished.

\section{Methodology}

\subsection{Simulation Model}

To validate the proposed control strategy, the predicted model is simulated in MATLAB/SIMULINK 2019a software (Mathworks). The collected 1000 battery-data are divided into 80\% (800), 10\% (100) and $10 \%$ (100) for training, validation, and testing; respectively. In shown in Figure 4a, different types of hyper-parameters e.g., sigmoid activation function, three neuron, one layer, and 0.1 valued learning rate are instigated to accomplish the training stage. The proposed controlling method to monitor the MPPT scheme and to estimate the SOC of the battery bank by dint of battery management system (BMS) is shown in Figure 4b. The MPPT mode generates maximum possible power from the available solar insolation under any atmospheric condition. 


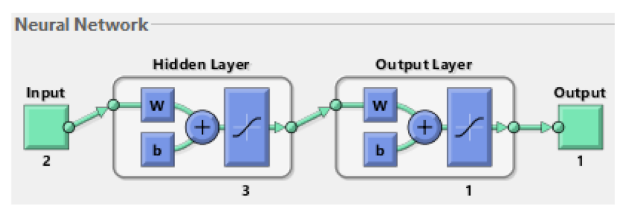

(a)

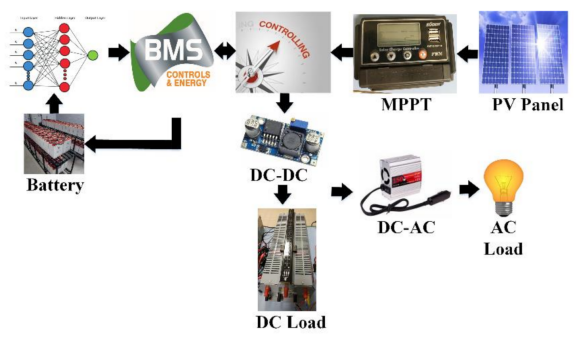

(b)

Figure 4. (a) Collected battery-data training using MATLAB toolbox; (b) Schematic diagram of the proposed model.

On the other side, BMS receives the battery voltage and current from measuring sensors and estimates the existing SOC by means of BPNN algorithm. The battery is kept in islanding mode if the PV can support the load-demand properly to reduce its utilization and elongate the battery lifetime. Furthermore, the battery section is charged or discharged frequently by following the PV power-supply involvement. From previous research [33-35], it is noticed that only $40 \%$ to $80 \%$ charged battery can function actively. More than $70 \%-80 \%$ SOC holding battery meets the over-charging mode at charging period and below the $30 \%-40 \%$ of SOC containing battery meets the deep-discharging mode at discharging period. As a result, this paper keeps the battery charging-discharging range as $40 \%$ to $80 \%$ SOC to lengthen the battery lifespan. The entire flowchart of the proposed BMS controlling technique is presented in Figure 5. In addition, the battery lifetime is adopted by following the Wöhler-curve-based ageing model which can be considered from (8)

$$
\text { Lifetime }=\frac{1}{L L}
$$

where $L L$ is the lifetime loss (in Ah) of the battery that is the function of DOD as well as DOD is the complementary to SOC.

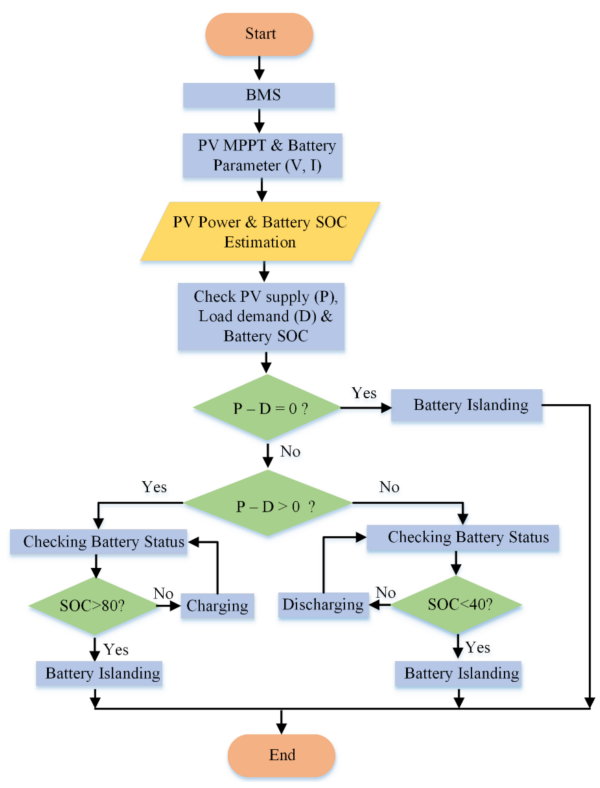

Figure 5. Flowchart for the entire system. 


\subsection{Experimental Model}

A physical prototype of the proposed model, as shown in Figure $6 a, b$ is developed in the laboratory environment. A 12 volt, 7 Ah lead-acid battery is installed with the solar module PV panel $\left(\mathrm{V}_{\mathrm{OC}}=21.6 \mathrm{~V}\right.$, $\left.\mathrm{I}_{\mathrm{SC}}=3.40 \mathrm{~A}, \mathrm{P}_{\mathrm{m}}=50 \mathrm{~W}\right)$ along with a $5 \mathrm{~W}$ AC bulb $(240 \mathrm{~V}, 50 \mathrm{~Hz})$ as a load. In the working prototype, PV solar panel, battery, and loads are connected including fuse and circuit breaker as well as the MATLAB/SIMULINK 2019a software is interfaced with dSPACE 1104 controller on Windows 10 professional operating system in a personal computer (PC) acer with 4.00 GB RAM, Intel(R), Core(TM) i5-3230 CPU @ 2.60 GHz. The integration of MATLAB Tools for dSPACE Code Generation block diagram is shown in Figure 7. The voltage and current sensors measure the voltage and current from the corresponding elements and provides the signal to the designed personal computer (PC) model through dSPACE1104 electronic board. The SIMULINK model analyzes the data and evaluates the PV power, battery SOC, and load power for the BMS controller. It is worth mentioning that the aim of this paper focuses on the battery system management through the proposed BMS that controls the charging, discharging, and islanding modes of the battery.

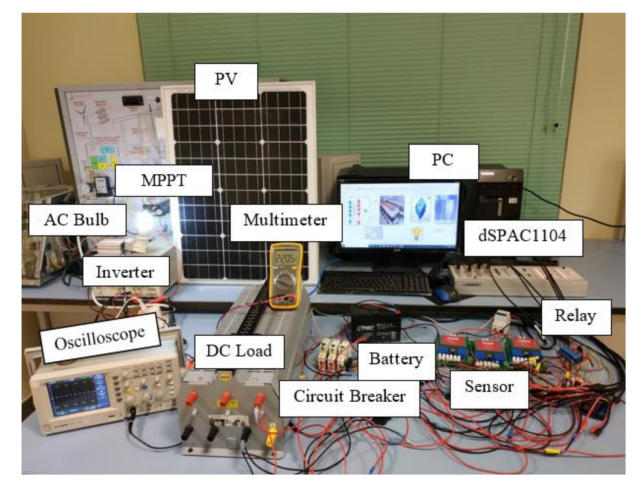

(a)

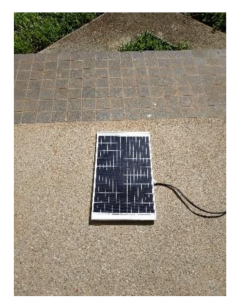

(b)

Figure 6. (a) Experimental setup of the developed hardware model; (b) Photovoltaic (PV) panel installation in the vicinity of the laboratory hardware model.

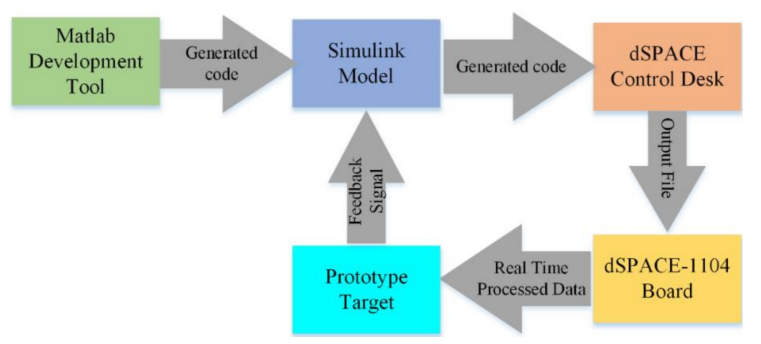

Figure 7. Integration of MATLAB-dSPACE Code Generation block diagram.

\section{Results and Discussion}

\subsection{Performance Statement}

The experiment was conducted from June to July, 2019 in the laboratory environment. On the first day as shown in Figure 8, the prototype was verified at $620 \mathrm{~W} / \mathrm{m}^{2}$ solar radiation and $29^{\circ} \mathrm{C}$ 
ambient temperature. The PV supply was sufficient (nearly $10.8 \mathrm{~W}$ ) on that day to support the $5 \mathrm{~W}$ load demand. Since, the battery was contented with the maximum $80 \%$ SOC, the storage system resulted in an islanding mode to extend the battery execution lifetime.
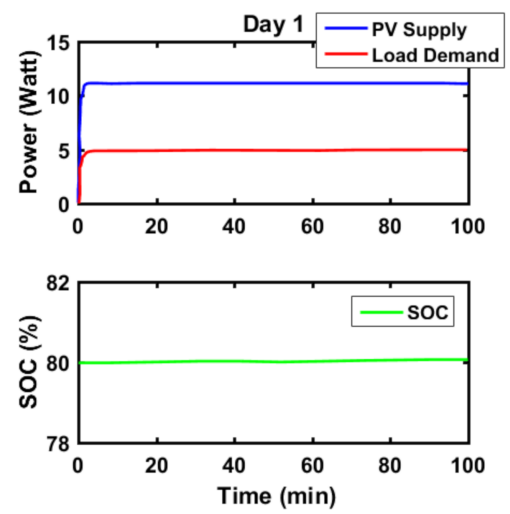

Figure 8. Experimental analysis for Day 1: $620 \mathrm{~W} / \mathrm{m}^{2}, 29^{\circ} \mathrm{C}$.

On the second day $\left(540 \mathrm{~W} / \mathrm{m}^{2}, 27^{\circ} \mathrm{C}\right), 65 \%$ SOC containing battery was experimented and BMS changed the battery to charging mode for that day as shown in Figure 9. Because 8.2 W PV supply was adequate to charge the battery together with supporting the load demand. On the third day, the developed system was carried out in $55 \% \mathrm{SOC}, 372 \mathrm{~W} / \mathrm{m}^{2}$ irradiance $23{ }^{\circ} \mathrm{C}$ atmospheric temperature. On this day, the PV supply ( $3.8 \mathrm{~W}$ ) was insufficient to support the load demand. Hence, the battery bank was brought to the discharging mode to cover the load as shown in Figure 10. On the fourth day $\left(322 \mathrm{~W} / \mathrm{m}^{2}, 21{ }^{\circ} \mathrm{C}\right)$, the BMS was examined with the minimum $40 \%$ SOC. As shown in Figure 11 , neither the PV supply, nor the battery source was able to deliver the load demand adequately. Hence, the BMS islanded the battery discharging file to maintain the battery life against deeper depth of discharge (DOD). The generated DC voltage is converted into AC voltage waveform as shown in Figure 12. Figure 12a shows the generated AC voltage from which the pure sine wave as shown in Figure $12 b$, is revealed for a particular period. Figure 12c shows the experimental modified AC signal obtained in the laboratory for the operation of low powered equipment.
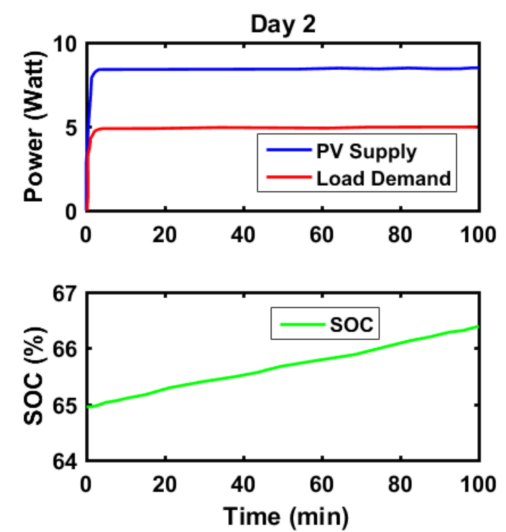

Figure 9. Experimental analysis for Day 2: $540 \mathrm{~W} / \mathrm{m}^{2}, 27^{\circ} \mathrm{C}$. 

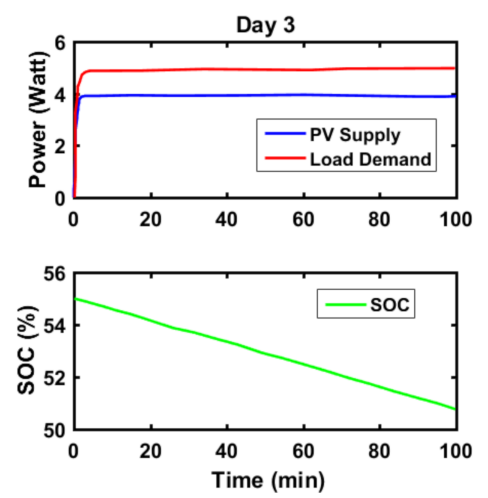

Figure 10. Experimental analysis for Day 3: $372 \mathrm{~W} / \mathrm{m}^{2}, 23^{\circ} \mathrm{C}$.
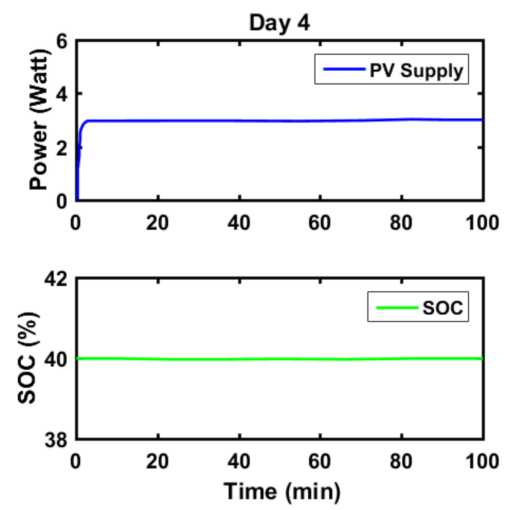

Figure 11. Experimental analysis for Day 4: $322 \mathrm{~W} / \mathrm{m}^{2}, 21^{\circ} \mathrm{C}$.

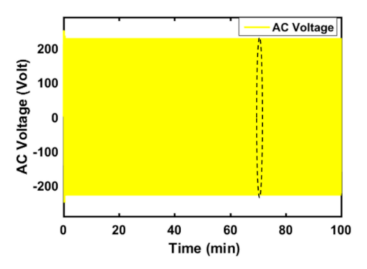

(a)

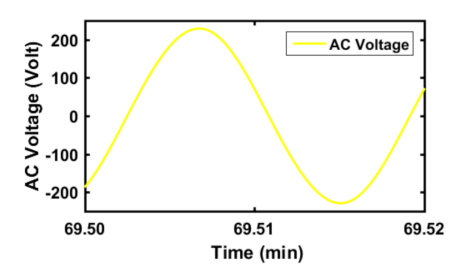

(b)

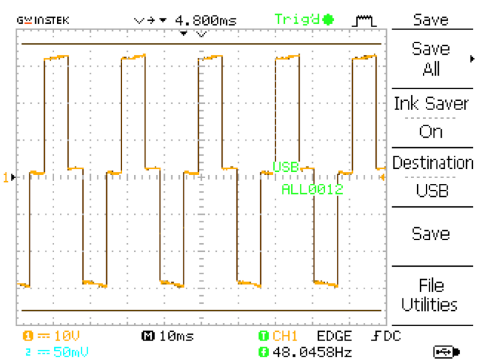

(c)

Figure 12. (a) Generation of AC voltage density; (b) Pure AC sine wave; (c) Modified AC sine wave production in Oscilloscope.

\subsection{Performance Validation}

The training and testing analysis for the accumulated battery-data are performed in MATLAB software by accomplishing the BPNN algorithm. In this concern as shown in Figure 13, the overall regression for training, validation and testing is brought about $99.507 \%$. Moreover, at the initial experiment, the actual SOC was calculated using Coulomb counting (CC) method. Figure 14 shows that though the initialization disparity of the estimated SOC is high relating to the actual SOC in consequence of the random accessed weights of BPNN algorithm, the inconsistency is minimized after some moments as a result of weight adjustment tactics. Along with this regard, Figure 15 indicates the RMSE $(0.082 \%)$ of the estimated SOC. Table 1 shows an accuracy comparison of the proposed method for lead-acid battery (LAB) with other techniques, i.e., support vector machine for regression (SVR), Kalman filter (KF), dual extended Kalman filter-auto regressive exogenous (DEKF-ARX), particle swarm optimization (PSO) and Open Circuit Voltage (OCV) published in the literature. The table shows that the proposed model results in the least MSE. The other principle of the proposed BMS controller is to elongate the working-life of the battery storage. 

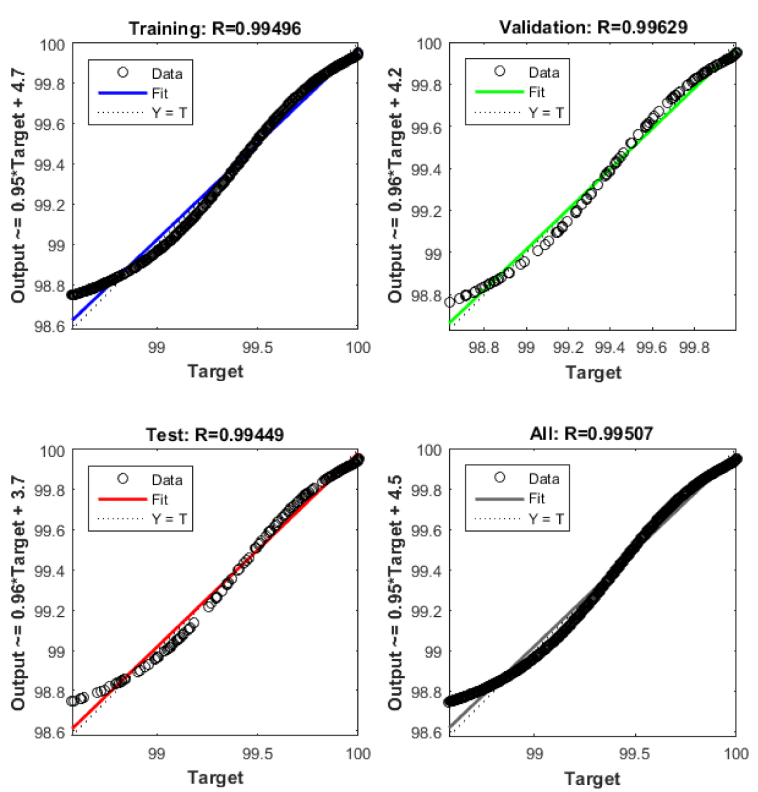

Figure 13. Training, Testing, and Validation results with regression.

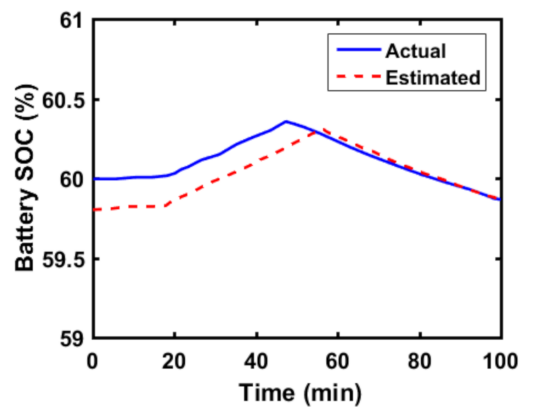

Figure 14. Comparison between Actual and Estimation SOC.

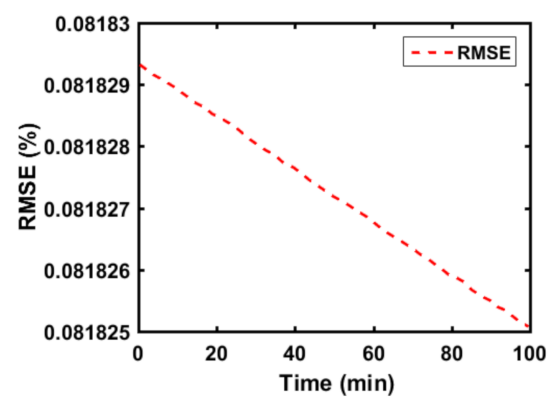

Figure 15. Root mean square error (RMSE) of the system.

Table 1. Comparison of SOC estimation accuracy.

\begin{tabular}{ccccc}
\hline Year & Ref. & Battery & SOC Algorithm & Error (\%) \\
\hline 2015 & {$[36]$} & LAB & SVR & 0.95 \\
2016 & {$[37]$} & LAB & KF & 1.7 \\
2017 & {$[38]$} & LAB & DEKF-ARX & 4.58 \\
2018 & {$[39]$} & LAB & PSO & 3.46 \\
2019 & {$[40]$} & LAB & OCV & 3.78 \\
2019 & {$[41]$} & LIB & BPNN & 1.2 \\
2019 & {$[42]$} & LIB & BPNN & 1.15 \\
2020 & Proposed Model & LAB & BPNN & 0.082 \\
\hline
\end{tabular}


Conventionally, load conducts the battery energy supply for all day-night that diminishes the storage lifespan. The projected model monitors the operation of PV supply, load, and battery by maintaining the SOC in the safest range. Moreover, the battery is discharged when the PV supply is insufficient to support the load demand only that assists to achieve the aforementioned goal. By following this novel method, a comparison between the conventional and projected model of the battery-lifetime is shown in Figure 16, of which it can be observed that the proposed model enhance battery lifetime compared to the conventional model. The selected battery is able to afford the $5 \mathrm{~W}$ light for around seven hours. To validate the robustness of the proposed model, a comparison between simulated and experimented modified AC sine wave is conducted as shown in Figure 17 which reveals good agreement between the experimental and simulation results. The proposed approach is easy to implement for already installed and new PV systems. It can be also adopted in many applications of the flexible ac transmission system (FACTS) devices and wind energy conversion systems [43-51].

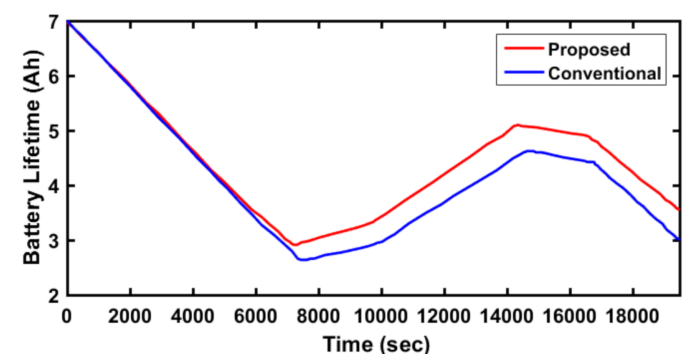

Figure 16. Battery Lifetime comparison between proposed and conventional model.

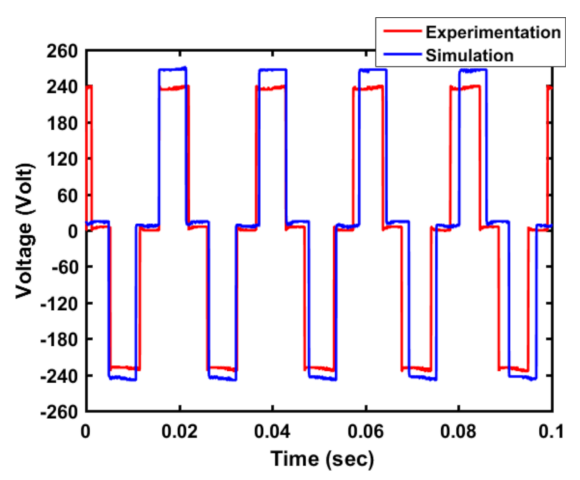

Figure 17. Comparison between simulation and experimentation Modified AC voltage.

\section{Conclusions}

Battery storage is an expensive but essential component for PV-battery integrated system to ensure the continuity of power supply during the cloudy days and night time. In this paper, a BMS that consists of PV model, P\&O MPPT technique and SOC estimation of battery is developed. Experimental data were simulated for analyzing the real-world application. Subsequently, the practical evaluation of the simulated model is developed to validate the robustness of the proposed model. dSPACE 1104 monitoring component upgrades the experimental qualification of the proposed model. The foremost objective of this research is to maintain the battery SOC within a protected range to avoid over-charging and deep-discharging that affects the operational life of the battery. Effective simulation and experimentation for well-regulated BMS is followed to implement the proposed structure of the PV-battery hybrid system. The control strategy observes the SOC of the lead-acid battery and takes decisions to achieve the anticipated operating goals and elongate the battery lifetime. The proposed SOC estimation technique results in a RMSE of $0.082 \%$ which is the least when compared with other techniques published in the literature. The proposed control approach for PV-BMS validation tests conducted on this platform are safe beyond the standard range of operation, specifically at initial stages in the development procedure. For future work, the utilization of historical data for SOC estimation as 
well as several kinds of adaptive algorithms, e.g., support vector machine (SVM), extreme learning machine (ELM), and restricted Boltzmann machine (RBM) could be conducted to recapitulate this study for on-grid section. The situation is worth stating that the internal temperature of the PV panel is a critical parameter that influence the efficiency and operational life of the entire system. This calls for further future investigation comprising the long-term experimentation before industrialization.

Author Contributions: M.O.Q. conceived the original idea; M.O.Q. and Y.B. wrote and edited the manuscript; H.B. investigation; M.L.H. and A.A.-S. supervised the study; M.M.R. and S.M.M. revised the final version of the paper. All authors have read and agreed to the published version of the manuscript.

Funding: This research was funded by Research and Innovation Management Center (RIMC), UNIMAS via Fundamental Research Grant Scheme, Ministry of Higher Education, Malaysia, grant number FRGS/1/2017/TK10/UNIMAS/03/1.

Conflicts of Interest: The authors declare no conflict of interest.

\section{References}

1. Ghenai, C.; Bettayeb, M. Modelling and performance analysis of a stand-alone hybrid solar PV/Fuel Cell/Diesel Generator power system for university building. Energy 2019, 171, 180-189. [CrossRef]

2. Castro, R. Data-driven PV modules modelling: Comparison between equivalent electric circuit and artificial intelligence based models. Sustain. Energy Technol. As sess. 2018, 30, 230-238. [CrossRef]

3. Gopi, R.R.; Sreejith, S. Converter topologies in photovoltaic applications-A review. Renew. Sustain. Energy Rev. 2018, 94, 1-14. [CrossRef]

4. Sundareswaran, K.; Vigneshkumar, V.; Palani, S. Development of a hybrid genetic algorithm/perturb and observe algorithm for maximum power point tracking in photovoltaic systems under non-uniform insolation. IET Renew. Power Gener. 2015, 9, 757-765. [CrossRef]

5. Trzmiel, G.; Głuchy, D.; Kurz, D. The impact of shading on the exploitation of photovoltaic installations. Renew. Energy 2020, 153, 480-498. [CrossRef]

6. Chong, L.W.; Wong, Y.W.; Rajkumar, R.K.; Isa, D. An optimal control strategy for standalone PV system with Battery-Supercapacitor Hybrid Energy Storage System. J. Power Sources 2016, 331, 553-565. [CrossRef]

7. Perdana, Y.S.; Muyeen, S.M.; Al-Durra, A.; Simoes, M.G.; Morales-Paredes, H.K. Direct Connection of Supercapacitor-Battery Hybrid Storage System to the Grid-tied Photovoltaic System. IEEE Trans. Sustain. Energy 2019, 10, 1370-1379. [CrossRef]

8. Saxena, N.; Hussain, I.; Singh, B.; Vyas, A.L. Implementation of a Grid-Integrated PV-Battery System for Residential and Electrical. IEEE Trans. Ind. Electron. 2018, 65, 6592-6601. [CrossRef]

9. Mohanty, S.; Subudhi, B.; Ray, P.K. A Grey Wolf-Assisted Perturb \& Observe MPPT Algorithm for a PV System. IEEE Trans. Energy Convers. 2017, 32, 340-347. [CrossRef]

10. Bendib, B.; Belmili, H.; Krim, F. A survey of the most used MPPT methods: Conventional and advanced algorithms applied for photovoltaic systems. Renew. Sustain. Energy Rev. 2015, 45, 637-648. [CrossRef]

11. Lasheen, M.; Abdel-Salam, M. Maximum power point tracking using Hill Climbing and ANFIS techniques for PV applications: A review and a novel hybrid approach. Energy Convers. Manag. 2018, 171, 1002-1019. [CrossRef]

12. Ahmed, J.; Salam, Z. An Enhanced Adaptive P\&O MPPT for Fast and Efficient Tracking under Varying Environmental Conditions. IEEE Trans. Sustain. Energy 2018, 9, 1487-1496. [CrossRef]

13. Abdel-Salam, M.; El-Mohandes, M.-T.; Goda, M. An improved perturb-and-observe based MPPT method for PV systems under varying irradiation levels. Sol. Energy 2018, 171, 547-561. [CrossRef]

14. Alik, R.; Jusoh, A. Modified Perturb and Observe (P\&O) with checking algorithm under various solar irradiation. Sol. Energy 2017, 148, 128-139. [CrossRef]

15. Ishaque, K.; Salam, Z.; Lauss, G. The performance of perturb and observe and incremental conductance maximum power point tracking method under dynamic weather conditions. Appl. Energy 2014, 119, 228-236. [CrossRef]

16. Tsuanyo, D.; Azoumah, Y.; Aussel, D.; Neveu, P. Modeling and optimization of batteryless hybrid PV (photovoltaic)/Diesel systems for off-grid applications. Energy 2015, 86, 152-163. [CrossRef] 
17. Sangwongwanich, A.; Yang, Y.; Sera, D.; Blaabjerg, F.; Angenendt, G.; Zurmühlen, S.; Sauer, D.U. Enhancing PV Inverter Reliability With Battery System Control Strategy. CPSS Trans. Power Electron. Appl. 2018, 3, 93-101. [CrossRef]

18. Huck, M.; Sauer, D.-U. Modeling transient processes in lead-acid batteries in the time domain. J. Energy Storage 2020, 29, 101430. [CrossRef]

19. Badeda, J.; Kwiecien, M.; Schulte, D.; Sauer, D. Battery State Estimation for Lead-Acid Batteries under Float Charge Conditions by Impedance: Benchmark of Common Detection Methods. Appl. Sci. 2018, 8, 1308. [CrossRef]

20. Lee, S.; Cherry, J.; Safoutin, M.; McDonald, J. Modeling and Validation of 12V Lead-Acid Battery for Stop-Start Technology. In Proceedings of the SAE International, Michigan, MI, USA, 4-6 April 2017; pp. 1-11.

21. Misyris, G.S.; Member, S.; Doukas, D.I.; Papadopoulos, T.A.; Member, S.; Labridis, D.P.; Member, S. State-of-Charge Estimation for Li-ion Batteries: A More Accurate Hybrid Approach. IEEE Trans. Energy Convers. 2019, 34, 109-119. [CrossRef]

22. Wei, Z.; Zhao, D.; He, H.; Cao, W.; Dong, G. A noise-tolerant model parameterization method for lithium-ion battery management system. Appl. Energy 2020, 268, 114932. [CrossRef]

23. Wei, Z.; Meng, S.; Xiong, B.; Ji, D.; Tseng, K.J. Enhanced online model identification and state of charge estimation for lithium-ion battery with a FBCRLS based observer. Appl. Energy 2016, 181, 332-341. [CrossRef]

24. Wei, Z.; Dong, G.; Zhang, X.; Pou, J.; Quan, Z.; He, H. Noise-Immune Model Identification and State of Charge Estimation for Lithium-ion Battery Using Bilinear Parameterization. IEEE Trans. Ind. Electron. 2020, 68, 312-323. [CrossRef]

25. Hannan, M.A.; Lipu, M.S.H.; Hussain, A.; Saad, M.H.; Ayob, A. Neural network approach for estimating state of charge of lithium-ion battery using backtracking search algorithm. IEEE Access 2018, 6, 10069-10079. [CrossRef]

26. Husnayain, F.; Utomo, A.R.; Priambodo, P.S. State of charge estimation for a lead-acid battery using backpropagation neural network method. In Proceedings of the 2014 International Conference on Electrical Engineering and Computer Science (ICEECS), Kuta, Indonesia, 24-25 November 2014; pp. 274-278. [CrossRef]

27. Martinez-Laserna, E.; Herrera, V.; Gandiaga, I.; Milo, A.; Sarasketa-Zabala, E.; Gaztañaga, H. Li-Ion Battery Lifetime Model's Influence on the Economic Assessment of a Hybrid Electric Bus's Operation. World Electr. Veh. J. 2018, 9, 28. [CrossRef]

28. Alramlawi, M.; Gabash, A.; Mohagheghi, E.; Li, P. Optimal operation of hybrid PV-battery system considering grid scheduled blackouts and battery lifetime. Sol. Energy 2018, 161, 125-137. [CrossRef]

29. Xiong, R.; Cao, J.; Yu, Q.; He, H.; Sun, F. Critical Review on the Battery State of Charge Estimation Methods for Electric Vehicles. IEEE Access 2017, 6, 1832-1843. [CrossRef]

30. Bani Ahmad, A.; Ooi, C.A.; Ishak, D.; Teh, J. State-of-Charge Balancing Control for ON/OFF-Line Internal Cells Using Hybrid Modular Multi-Level Converter and Parallel Modular Dual L-Bridge in a Grid-Scale Battery Energy Storage System. IEEE Access 2019, 7, 131-147. [CrossRef]

31. Burzyński, D.; Pietracho, R.; Kasprzyk, L.; Tomczewski, A. Analysis and Modeling of the Wear-Out Process of a Lithium-Nickel-Manganese-Cobalt Cell during Cycling Operation under Constant Load Conditions. Energies 2019, 12, 3899. [CrossRef]

32. Yonis Buswig, Y.M.; Qays, O.; Affam, A.; Albalawi, H.; Othman, A.-K.; Julai, N.; Sy Yi, S. Designing a control system based on SOC estimation of BMS for PV-Solar system. Int. J. Integr. Eng. 2020, 12, 148-157. [CrossRef]

33. Devarakonda, L.; Hu, T. Effects of rest time on discharge response and equivalent circuit model for a lead-acid battery. J. Power Sources 2015, 282, 19-27. [CrossRef]

34. Pavlov, D. Invention and Development of the Lead-Acid Battery. In Lead-Acid Batteries Science and Technology; Elsevier: Amsterdam, the Netherlands, 2017; pp. 3-32. [CrossRef]

35. Dell, R.M.; Moseley, P.T.; Rand, D.A.J. Batteries and Supercapacitors for Use in Road Vehicles. In Towards Sustainable Road Transport; Elsevier: Amsterdam, the Netherlands, 2014; pp. 217-259.

36. Surendar, V.; Mohankumar, V.; Anand, S.; Prasanna, V.D. Estimation of State of Charge of a Lead Acid Battery Using Support Vector Regression. Procedia Technol. 2015, 21, 264-270. [CrossRef]

37. Morstyn, T.; Momayyezan, M.; Hredzak, B.; Agelidis, V.G. Distributed Control for State-of-Charge Balancing Between the Modules of a Reconfigurable Battery Energy Storage System. IEEE Trans. Power Electron. 2016, 31, 7986-7995. [CrossRef] 
38. Tran, N.-T.; Khan, A.; Choi, W. State of Charge and State of Health Estimation of AGM VRLA Batteries by Employing a Dual Extended Kalman Filter and an ARX Model for Online Parameter Estimation. Energies 2017, 10, 137. [CrossRef]

39. Azzollini, I.A.; di Felice, V.; Fraboni, F.; Cavallucci, L.; Breschi, M.; Rosa, A.D.; Zini, G. Lead-Acid Battery Modeling Over Full State of Charge and Discharge Range. IEEE Trans. Power Syst. 2018, 33, 6422-6429. [CrossRef]

40. Al Hadi, A.M.R.; Ekaputri, C.; Reza, M. Estimating the state of charge on lead acid battery using the open circuit voltage method. J. Phys. Conf. Ser. 2019, 1367, 1-7. [CrossRef]

41. Qays, O.; Buswig, Y.; Anyi, M. Active Cell Balancing Control Method for Series-Connected Lithium-Ion Battery. Int. J. Innov. Technol. Explor. Eng. 2019, 8, 2424-2430. [CrossRef]

42. Qays, O.; Buswig, Y.; Hossain, L.; Ieee, S.M.; Rahman, M.; Abu-siada, A.; Ieee, S.M.; Modeling, A.C. Active cell balancing control strategy for parallel connected LiFePO4 batteries. CSEE J. Power Energy Syst. 2020. [CrossRef]

43. Abdou, A.F.; Abu-Siada, A.; Pota, H.R. Application of a STATCOM for Damping Subsynchronous Oscillations and Transient Stability Improvement. In Proceedings of the AUPEC Conference, Brisbane, Australia, 25-28 September 2011.

44. Alharbi, Y.M.; Yunus, A.M.S.; Abu-Siada, A. Application of STATCOM to Improve the High-Voltage-Ride-Through Capability of Wind Turbine Generator. In Proceedings of the IEEE Innovation Smart Grid Technologies Conference, Perth, WA, Australia, 13-16 November 2011.

45. Sheikh, M.R.I.; Muyeen, S.M.; Takahashi, R.; Murata, T.; Tamura, J. Minimization of Fluctuations of Output Power and Terminal Voltage of Wind Generator by Using STATCOM/SMES. In Proceedings of the IEEE PowerTech 2009 Conference, Paper No. 231, Bucharest, Romania, 28 June-2 July 2009.

46. Alharbi, Y.M.; Yunus, A.M.S.; Abu-Siada, A. Application of UPFC to Improve the LVRT Capability of Wind Turbine Generator. In Proceedings of the AUPEC Conference, Bali, Indonesia, 26-29 September 2012.

47. Sheikh, M.R.I.; Muyeen, S.M.; Takahashi, R.; Tamura, J. Smoothing Control of Wind Generator Output Fluctuations by PWM Voltage Source Converter and Chopper Controlled SMES. Eur. Trans. Electr. Power 2011, 21, 680-697. [CrossRef]

48. Muyeen, S.M.; Takahashi, R.; Murata, T.; Tamura, J. Transient Stability Enhancement of Variable Speed Wind Turbine Driven PMSG with Rectifier-Boost Converter-Inverter. In Proceedings of the 18th International Conference on Electrical Machines (ICEM 2008), Vilamoura, Portugal, 6-9 September 2008.

49. Okedu, K.E.; Muyeen, S.M.; Takahashi, R.; Tamura, J. Comparative Study between Two Protection Schemes for DFIG-based Wind Generator. In Proceedings of the International Conference on Electrical Machines and Systems (ICEMS2010), Incheon, Korea, 10-13 October 2010. Paper No. D20100226-79.

50. Okedu, K.E.; Muyeen, S.M.; Takahashi, R.; Tamura, J. Improvement of Fault Ride through Capability of Wind Farm using DFIG Considering SDBR. In Proceedings of the Conference CDROM: European Conference on Power Electronics and Applications (EPE 2011), Birmingham, UK, 30 Augsut-1 September 2011.

51. Yunus, A.M.S.; Abu-Siada, A.; Masoum, M.A.S. Improvement of LVRT Capability of Variable Speed Wind Turbine Generators Using SMES Unit. In Proceedings of the IEEE Innovation Smart Grid Technologies Conference, Perth, WA, Australia, 13-16 November 2011.

Publisher's Note: MDPI stays neutral with regard to jurisdictional claims in published maps and institutional affiliations.

(C) 2020 by the authors. Licensee MDPI, Basel, Switzerland. This article is an open access article distributed under the terms and conditions of the Creative Commons Attribution (CC BY) license (http://creativecommons.org/licenses/by/4.0/). 